\title{
Protection of pigs against the Aujeszky's disease by a new oily inactivated vaceine. Practical eonsequences
}

\author{
P. VANNIER, J.-P. TILLON, B. TOMA*, J.-F. DELAGNEAU**, \\ R. LOQUERIE**, P. PRUNET** \\ Station de Pathologie Porcine, \\ 22140 Ploufragan \\ * Laboratoire de Maladies contagieuses, \\ École nationale vétérinaire, \\ 94701 Maisons-Alfort \\ ** Laboratoire Roger Bellon, \\ Centre de Recherches Vétérinaires, \\ Villaines-les-Rochers, \\ 31790 Azay-le-Rideau
}

The immunogenic properties of a new oily inactivated vaccine were stuclied in pigs after weaning and in piglet from immunized sows. The presence of a high level of circulating antibodies in these animals was accompanied by resistarce of the pigs after challenge with the virulent strain. A secondary reaction appeared at the moment of the booster injection and seemed to be an allergic phenomenon related with the virus protein. In spite of this disadvantage this vaccine might be useful in prevention of the Aujeszky's clisease.

\section{Internal parasites in suckling piglets related to the parasites of the sow and hygienic conditions in the farms}

\author{
J.-P. RAYNALD, A. BOLCHET
}

Station de R. et $D$. Vétérinaire et Nutrition animale, Pfiser International, B.P. 42, $3 \pi 100$ Amboise

We controlled the parasites and lesions found in piglets at weaning when the sow voided a high level of nematode eggs : on an average, in 30 sows at farrowing, $3550 \mathrm{eggs} / \mathrm{g}$ of Oesophagostomum, $73 \mathrm{cggs} / \mathrm{g}$ of Hyostrongylus and $50 \mathrm{cggs} / \mathrm{g}$ of Ascaris. 30 sows and litters in $\mathrm{I}+$ farms were controlled i.e. a total of 262 piglets for egg counts, among which 62 were killed for worm counts. After having distributed the sows and their litters according to the actual hygienic conditions, we controlled: 